\title{
Study of the Cost and Return of Electricity Generated from Thermoelectric Electrical Generator of Energy Saving Equipment for Gas Store - A Case Study Applied to Small Business Sector
}

\author{
Patcharin Chatsuwanying
}

\begin{abstract}
This study investigates the cost and return of electricity generated from Thermoelectric electrical generator of energy saving equipment for gas store a case study applied to small business sector. Study and collect data using in-depth interviews and observers of the thermoelectric generator of the researcher Study and Development Thermoelectric electrical generator of energy saving equipment for gas store. The test case is divided into 3 cases. The test case is without heating water ( 0 liters per minute). Case $B$ is tested with cooling water ( 5 liters per minute) and Case $\mathrm{C}$ is checked with hot water capacity. ( 9 liters per minute) and data collection using in-depth interviews to find out about the store.

A study of costs and benefits found that case studies applied to small business sector. When computed with average data collected, it was found that in 1 year, Case $C$ was tested with cooling water ( 9 liters per minute). It can produce electricity at 5.198 watts. The amount of electricity produced it save electricity charge 93.01 baht and the payback period is 12.90 years. The study found that the device can produce DC power. And the power can be applied to the small electrical appliances. Example charging electricity to a cell phone. But with a high investment compared to the amount of electricity produced. As a result, the payback period is longer.
\end{abstract}

Keywords - Costs and returns, Thermoelectric

\section{INTRODUCTION}

Today is the era of technology and digital. New technologies and innovations have been developed to create a large number of human facilities, resulting in higher electricity consumption every year. To meet the demand for the development and use of technology. Figure 1 shows the electricity generation of the Electricity Generating Authority of Thailand (EGAT). Over the past 10 years. In 2006 - 2016 the difference is $25 \%$.

Patcharin Chatsuwanying, Lecturer, Faculty of Accounting, Siam Technology College, 46 Jarunsanitwong10 rd., Thapra branch, Bangkok-yai district, Bangkok 10600 Thailand.

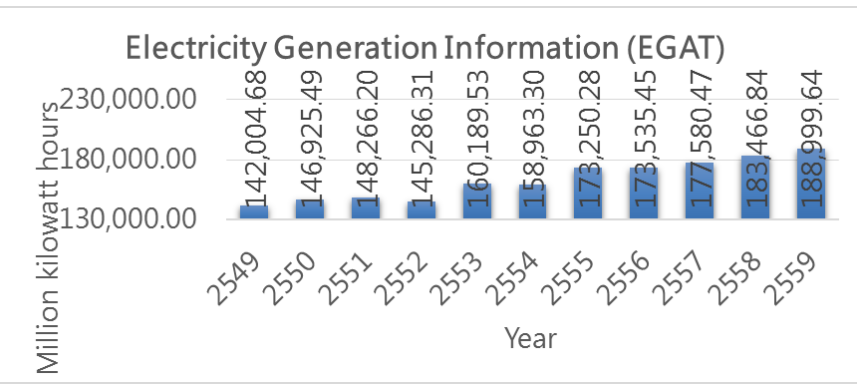

The increased use of electricity has made all sectors of the public and private sectors aware of future energy problems. Energy-saving devices and alternative energy sources are introduced. One of them is the heat source lost from the furnace. Researchers have developed the device. Thermoelectric generators of power saving appliances for gas furnaces have the ability to produce direct current from the heat of the furnace.

This research is to study the cost of production of thermoelectric generator for energy saving appliances for cooking gas. And return on direct electricity generation. When applied to the small business sector, such as the food shop. noodle shop Tofu Shop To analyze the financial return. And the payback period of the device.

\section{OBJECTIVES}

1. Study cost and return on investment. Of Thermoelectric Generator of Energy Saving Device for Gas Cooker.

2. Case study of thermoelectric generators for energy saving devices for gas cookers to apply to small business sector such as restaurant, food stalls.

\section{SCOPE AND RESEARCH METHODOLOGY}

\section{A. Scope of study}

This study is to study the cost and return of electricity generated from the thermoelectric generator of energy saving equipment for cooking gas. Based on the research. [1]Study and development of thermoelectric generator of energy saving equipment for cooking gas.

\section{B. Research methodology}

\subsubsection{Primary Data}

1. Data collection using in-depth interviews. And observers of the thermoelectric generator of the researcher "Study and 
Development Thermoelectric electrical generator of energy saving equipment for gas store”. Study patterns and working methods for thermoelectric electrical generator of energy saving equipment for gas store.

2. Data collection using in-depth interviews to find the information of the shop such as time to open - turn off the stove and electricity per kilowatt hour.

\subsubsection{Secondary Data}

1. Study on information on the electricity generation of the thermoelectric generator of energy saving equipment for cooking gas from similar research.

2. Collection of data by gathering information on various expenses. Used in the production of thermoplastic generators of energy saving appliances for cooking gas.

3.2.3 Analysis of Return on Investment and Duration of Investment

1) Net Present Value

2) Internal Rate of Return: IRR

\section{3) Payback Period: PB \\ Payback Period $=$ Total Investment Annual Energy Cost Saving}

\section{RESUlTS}

TABLE I INTERVIEW DATA AND INSIGHTS OF SMALl BuSINESS SECTOR 3 STORES IN BANGKOK NOI, BANGKOK IN MARCH 2018

\begin{tabular}{|c|c|c|c|c|c|c|}
\hline $\begin{array}{c}\text { Stor } \\
\mathrm{e}\end{array}$ & $\begin{array}{c}\text { Time } \\
\text { Open } \\
- \\
\text { Clos } \\
\text { e }\end{array}$ & $\begin{array}{l}\text { Workin } \\
\text { g Time }\end{array}$ & $\begin{array}{c}\text { Electricit } \\
\text { y Bill }\end{array}$ & $\begin{array}{l}\text { Kilowat } \\
\text { t hours } \\
\text { : month }\end{array}$ & $\begin{array}{l}\text { Baht : } \\
\text { Kilowat } \\
\text { t hours }\end{array}$ & $\begin{array}{c}\text { Workin } \\
\text { g day : } \\
\text { Year }\end{array}$ \\
\hline 1 & $\begin{array}{l}4.00- \\
16.00\end{array}$ & 12 & 1,324 & 331 & 4.0 & 360 \\
\hline 2 & $\begin{array}{l}6.00- \\
20.00\end{array}$ & 14 & 8,228 & 1,848 & 4.5 & 360 \\
\hline 3 & $\begin{array}{r}15.00 \\
-2.00\end{array}$ & 11 & 542 & 149 & 3.6 & 360 \\
\hline \multicolumn{2}{|c|}{ Average } & 12.33 & $3,364.67$ & 776.00 & 4.0 & 360 \\
\hline
\end{tabular}

Collection of electricity data for the small business sector 3 stores in March 2018 found that 3 stores have different electricity consumption. And the time of opening - closing the unequal. The average working hours of the three stores were 12.33 hours, the average electricity was 3,364.67 Baht, the average $\mathrm{kWh}$ was 776.00 kilowatt hours and the average was 4.0 Baht per kilowatt hour. Assume 1 year is 360 working days.
TABLE II STUDY AND DEVELOPMENT OF THERMOELECTRIC GENERATOR OF ENERGY SAVING DEVICE FOR GAS COOKER AND THE ELECTRICITY GENERATED FROM THE CALCULATION WITH THE INFORMATION FROM THE STORE.

\begin{tabular}{|c|c|c|c|c|c|}
\hline $\begin{array}{c}\text { Cas } \\
\text { e }\end{array}$ & $\begin{array}{c}\text { Maximu } \\
\text { m power }\end{array}$ & $\begin{array}{c}\text { Workin } \\
\text { g Time }\end{array}$ & $\begin{array}{c}\text { Baht : } \\
\text { Kilowatt } \\
\text { hours }\end{array}$ & $\begin{array}{c}\text { Workin } \\
\text { g day : } \\
\text { Year }\end{array}$ & $\begin{array}{c}\text { Electricity } \\
\text { generation } \\
\text { (Baht : year) }\end{array}$ \\
\hline $\begin{array}{c}\text { Cas } \\
\text { e A }\end{array}$ & 0.493 & 12.33 & 4.0 & 360 & 8.82 \\
\hline $\begin{array}{c}\text { Cas } \\
\text { e B }\end{array}$ & 4.623 & 12.33 & 4.0 & 360 & 82.72 \\
\hline $\begin{array}{c}\text { Cas } \\
\text { e C }\end{array}$ & 5.198 & 12.33 & 4.0 & 360 & 93.01 \\
\hline
\end{tabular}

Based on research data Study and Development Thermoelectric electrical generator of energy saving equipment for gas store. Researchers developing thermoelectric generators have divided the experiment into three cases. Case $\mathrm{C}$ was tested by the cooling water ( 9 liters per minute) can generate 5.198 watts of electricity. When calculated with the average data collected, it is estimated that in one year, the electricity produced can be used to save electricity 93.01 baht, which has the highest electricity production.

TABLE III COST DATA For THERMOELECTRIC GENERATOR OF ENERGY SAVING DEVICE FOR GAS COOKER

\begin{tabular}{|c|c|c|c|c|}
\hline $\begin{array}{c}\text { Numbe } \\
\mathbf{r}\end{array}$ & List & Unit & Baht : Unit & Total (Baht) \\
\hline 1 & $\begin{array}{c}\text { Thermoelectric } \\
\text { (TEG1-12706) }\end{array}$ & 12 & 50 & 600 \\
\hline $\mathbf{2}$ & Steel, knots etc. & 1 & 200 & 200 \\
\hline 3 & $\begin{array}{c}\text { Equipment } \\
\text { Water cooled }\end{array}$ & 4 & 100 & 400 \\
\hline
\end{tabular}

Based on research data. Study and Development of Thermoelectric Generator of Energy Saving Device for Gas Cooker Researchers have developed thermoelectric generators. Total cost is 1,200 Baht.

TABLE IV RETURN ON INVESTMENT

\begin{tabular}{|c|c|c|c|c|c|}
\hline & $\begin{array}{c}\text { Electricity } \\
\text { generation } \\
\text { (Baht per } \\
\text { Case }\end{array}$ & $\begin{array}{c}\text { Investmen } \\
\mathrm{t}\end{array}$ & $\begin{array}{c}\text { Payback } \\
\text { (Year) }\end{array}$ & IRR & NPV \\
(บาท)
\end{tabular}

*IRR and NPV think of a 15 year period.

Based on research data. Study and Development of Thermoelectric Generator of Energy Saving Device for Gas Cooker Case Study Applied to Small Business Sector. When the amount of electricity produced is calculated to calculate the payback period. Internal rate of return the net present value of 
Case $\mathrm{C}$ is 12.90 years. The internal rate of return is $2.24 \%$ and the net present value is 195.13 baht. Make the payback time as fast as possible.

\section{SUMMARY OF RESEARCH RESULTS}

A study of the cost and return of electricity generated from the thermoelectric generators of energy saving devices for gas fired boilers. Case Study Applied to Small Business Sector the cost of producing the machine was 1,220 baht. The experiment in the case $\mathrm{C}$ was tested with cooling water (9 liters per minute). The electricity generated was 5.198 watts. In one year, the electricity generated was 93.01 baht. The payback period was 12.90 years. The internal rate was $2.24 \%$ and the net present value was 195.13 baht. And Case B was tested with cooling water ( 5 liters per minute).

\section{SugGestions}

The results of the study show that the cost and return of electricity generated from the thermoelectric generator of energy saving equipment for cooking gas. Case Study Applied to Small Business Sector There is a long payback period. Thermoelectricity should be installed more than 12 units in order to increase the amount of electricity produced. In order to have a faster payback period.

\section{REFERENCES}

[1] Khankaew, J. (2016). The Financial Cost Benet Analysis of Shred Artifact Products, Ban Buag Pao

Woman's Group, Nhong - Yhang, Sansai, Chiang Mai. Academic Journal The Far Eastern University Year 10 Issue 2

[2] Department of Alternative Energy Development and Effciency Ministry of Energy. (2007). Project

Evaluation Tool. Browse 2018, March 15, From

[3] Electricity Generating Authority of Thailand. Browse 2018, March 30, From http://www.egat.co.th.

[4] AdminhoonDB. (2013). Net Present Value. Browse 2018, March 30, From http://hoondb.com/ net-present-value/

[5] Panklid, T. (Dr.). (2014). Energy Saving Equipment for House Cooking Stove with Electric Generator.

Faculty of Technology Siam Technology College

[6] Aujirapongpan, S. (Dr.). (2009). Managerial Accounting. Bangkok Mc Graw Hill Education 